\title{
Genetic diversity in table grapes based on RAPD and microsatellite markers
}

\author{
Patrícia Coelho de Souza Leão(1) and Sérgio Yoshimitsu Motoike ${ }^{(2)}$
}

\begin{abstract}
(1)Embrapa Semiárido, Rodovia BR 428, Km 152 Caixa Postal 23, CEP 56300-970 Petrolina, PE, Brazil. E-mail: patricia@cpatsa.embrapa.br (2)Universidade Federal de Viçosa, Departamento de Fitotecnia, Avenida P.H. Rolfs s/nº, Campus Universitário, CEP 36570-000 Viçosa, MG, Brazil. E-mail: sergiomotoike@gmail.com
\end{abstract}

\begin{abstract}
The objective of this work was to analyze the genetic diversity of 47 table grape accessions, from the grapevine germplasm bank of Embrapa Semiárido, using 20 RAPD and seven microsatellite markers. Genetic distances between pairs of accessions were obtained based on Jaccard's similarity index for RAPD data and on the arithmetic complement of the weighted index for microsatellite data. The groups were formed according to the Tocher's cluster analysis and to the unweighted pair-group method with arithmetic mean (UPGMA). The microsatellite markers were more efficient than the RAPD ones in the identification of genetic relationships. Information on the genetic distance, based on molecular characteristics and coupled with the cultivar agronomic performance, allowed for the recommendation of parents for crossings, in order to obtain superior hybrids in segregating populations for the table grape breeding program of Embrapa Semiárido.
\end{abstract}

Index terms: Vitis vinifera, cluster analysis, genetic divergence, grapevine, multivariate analysis.

\section{Diversidade genética em uvas de mesa por meio de marcadores moleculares RAPD e microsatélites}

\begin{abstract}
Resumo - O objetivo deste trabalho foi analisar a diversidade genética de 47 acessos de uvas de mesa, procedentes do Banco de Germoplasma de Videira da Embrapa Semiárido, por meio de 20 marcadores moleculares RAPD e sete marcadores microsatélites. Distâncias genéticas entre pares de acessos foram obtidas com base no índice de similaridade de Jaccard para marcadores RAPD e no complemento aritmético do índice ponderado para dados de microsatélites. Os grupos foram formados de acordo com a análise de agrupamento de Tocher e com o método de agrupamento não ponderado (UPGMA). Os marcadores microsatélites foram mais eficientes do que os RAPD na identificação das relações de parentesco. As informações de distância genética, baseadas em características moleculares e aliadas ao desempenho agronômico das cultivares, permitiram a recomendação de parentais para cruzamentos, para a obtenção de híbridos superiores nas populações segregantes do programa de melhoramento de videira da Embrapa Semiárido.
\end{abstract}

Termos para indexação: Vitis vinifera, análise de agrupamento, divergência genética, videira, análise multivariada.

\section{Introduction}

The development of new grape cultivars adapted to subtropical and tropical conditions has been a major goal for grape breeding programs in Brazil (Ritschel et al., 2010). In Northeastern Brazil, the main objective of recent grape breeding projects has been the development of seedless table grapes, which are more resistant to diseases and well-adapted to the warm and dry environment of the Brazilian semi-arid region.

The knowledge of the genetic divergence can help breeders to concentrate efforts on the most promising combinations. The heterosis expressed in crosses is directly related to the genetic divergence between parents. The feasibility of studying genetic divergence as a criterion for selecting parents for hybridization has been demonstrated for several species, among them grapevine (Oliveira et al., 2005).

DNA molecular markers have been widely used to assess the grapevine genetic diversity and germplasm characterization. The RAPD markers, utilized to study grapevine genetic divergence, have been reported as efficient, despite their lower reproducibility, in comparison to other molecular markers (Herrera et al., 2002; Ulanovsky et al., 2002; Pinto-Carnide et al., 2003; Kocsis et al., 2005). The development of a set of microsatellite reference alleles for grapevine cultivar identification, fingerprinting and germplasm characterization was proposed by using six microsatellite loci and 13 cultivars by This et al. (2004). This set of six microsatellite loci - VVMD5, VVMD7 (Bowers et al., 1996), VVMD27 (Bowers

Pesq. agropec. bras., Brasília, v.46, n.9, p.1035-1044, set. 2011 
et al., 1999), VrZag62, VrZag79 (Sefc et al., 1999) and VVS2 (Thomas \& Scott, 1993) - is recommended for molecular characterization of grapevine germplasm collections, as well as for developing a unique database containing the alleles of all known grape cultivars. In recent decades, microsatellite markers have been widely used for the characterization of grapevine collections in several countries (Fatahi et al., 2003; Costantini et al., 2005; Martínez et al., 2006; Almadanim et al., 2007; Fernández-González et al., 2007; Leão et al., 2009).

The objective of this work was to analyse the genetic diversity of 47 table grape accessions, from the grapevine germplasm bank of Embrapa Semiárido, using 20 RAPD and seven microsatellite markers, for selecting parents with higher heterotic potential, allowing for crosses and the development of new seedless table grape cultivars adapted to the environmental conditions of Northeastern Brazil.

\section{Materials and Methods}

Forty-seven table grape accessions from the grapevine germplasm bank of Embrapa Semiárido, Juazeiro, BA, Brazil, were analyzed (Table 1). The cultivars were selected for their desirable agronomic traits and potential for use as parents in a table grape breeding program.

Genomic DNA was extracted using a modified CTAB protocol (Lodhi et al., 1994). In the final step, DNA pellets were suspended in $100 \mu \mathrm{L}$ of $1 \mathrm{X}$ Tris-EDTA buffer, and stored at $-20^{\circ} \mathrm{C}$. DNA quality was assessed on agarose gel $0.8 \%(\mathrm{w} / \mathrm{v})$ stained with ethidium bromide solution $\left(10 \mathrm{mg} \mathrm{mL}^{-1}\right)$.

One hundred and forty RAPD primers (Operon Technologies, Alameda, CA, USA) were initially screened for six grape cultivars. Twenty primers which produced reproducible and polymorphic bands were used to amplify all cultivars. Polymerase chain reaction (PCR) amplification was performed in 12.5 $\mu \mathrm{L}$ final volume containing $10 \mathrm{ng} \mu \mathrm{L}^{-1}$ template DNA, $1.25 \mu \mathrm{L}$ 10X PCR buffer (Invitrogen Co., Carlsbad, CA, USA), $25 \mathrm{mmol} \mathrm{L}^{-1} \mathrm{MgCl}_{2}$ (Invitrogen), $2.5 \mathrm{mmol} \mathrm{L}^{-1}$ of each dNTP, $4 \mathrm{mmol} \mathrm{L}^{-1}$ of each primer, $10 \mathrm{mg} \mathrm{mL}^{-1}$ BSA (bovine serum albumin) and 1 unit Taq DNA polymerase (Invitrogen). Amplification was done in a MJ Research PTC-100 thermal cycler (GMI Inc., Ramsey, Minnesota, USA), programmed for two cycles of $1 \mathrm{~min}$ at $94^{\circ} \mathrm{C}, 30 \mathrm{~s}$ at $35^{\circ} \mathrm{C}$, and $1 \mathrm{~min}$ at $7^{\circ} \mathrm{C}$, followed by 40 cycles of $15 \mathrm{~s}$ at $94^{\circ} \mathrm{C}, 30 \mathrm{~s}$ at $35^{\circ} \mathrm{C}, 1 \mathrm{~min}$ at $72^{\circ} \mathrm{C}$, and a final extension step of $7 \mathrm{~min}$ at $72^{\circ} \mathrm{C}$. Amplification products were resolved by electrophoresis on $1.5 \%$ agarose gels run at $100 \mathrm{~V}$ for 3 hours in $1 \mathrm{X}$ TAE buffer containing ethidium bromide solution $\left(10 \mathrm{mg} \mathrm{mL}^{-1}\right)$.

Seven well-characterized, highly polymorphic grapevine markers with simple sequence repeat (SSR) were used: VVS2 (Thomas \& Scott, 1993); VVMD5, VVMD7, VVMD27, VVMD31 (Bowers et al., 1996, 1999); VrZAG79 and VrZAG62 (Sefc et al., 1999). One primer in each primer pair was 5'-labelled with one of the following fluorescent dyes: 6-FAM, HEX and NED. The PCR amplification was done separately for each locus in $10 \mu \mathrm{L}$ final volume containing $2.5 \mathrm{ng} \mu \mathrm{L}^{-1}$ template DNA, 10 pmol of each primer, $2.5 \mathrm{mmol} \mathrm{L}^{-1}$ of each dNTP (Applied Biosystems, Foster City, CA, USA), $1 \mu \mathrm{L}$ 10X Gold PCR buffer

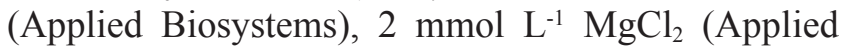
Biosystems) and 0.5 units AmpliTaq Gold DNA polymerase (Applied Biosystems). The PCR reactions were carried out using a MJ Research PTC-100 thermal cycler. The cycling program for all markers consisted of the following steps: $5 \mathrm{~min}$ at $95^{\circ} \mathrm{C}$, followed by 35 cycles of $30 \mathrm{~s}$ at $95^{\circ} \mathrm{C}, 45 \mathrm{~s}$ at $60^{\circ} \mathrm{C}, 1 \mathrm{~min}$ at $72^{\circ} \mathrm{C}$, and a final extension step of $7 \mathrm{~min}$ at $72^{\circ} \mathrm{C}$. Amplifications were checked by running an aliquot of $4 \mu \mathrm{L}$ of the PCR reaction product on $2 \%$ ethidium-bromide-stained agarose gels. Aliquots $(1.7 \mu \mathrm{L})$ of PCR products were mixed with $0.7 \mu \mathrm{L}$ of formamide, $0.4 \mu \mathrm{L}$ of dye and $0.2 \mu \mathrm{L}$ of DNA size standard Genescan-500 ROX (Applied Biosystems). Samples were denatured at $94^{\circ} \mathrm{C}$ for $2 \mathrm{~min}$, and loaded onto an ABI 377 DNA sequencer (Applied Biosystems). To obtain consistent and reliable results, each sample was amplified and analyzed twice at each marker. Four grape cultivars with well-established SSR profiles (Chardonnay, Carignane, Riesling and Thompson Seedless) were loaded on each gel for consistent scoring from one gel to another.

RAPD bands were scored for their presence (1) or absence (0), and the resulting data matrices were analyzed using the Genes 2007.0.0 software (Cruz, 2008). Similarity matrices were computed with the Jaccard's coefficient.

SSR fingerprints were detected with GeneScan analysis software v. 3.1, and the alleles were scored using the Genotyper DNA fragment analysis software v. 2.5.2. (Applied Biosystems). The similarity 
index between two individuals was estimated by the arithmetic complement of the weighted index. A dendrogram was constructed by cluster analysis based on the UPGMA algorithm. The input data were also processed by cluster analysis, using the Tocher's optimization method (Cruz et al., 2004).

Table 1. Forty-seven table grape accessions (name, geographical origin, species and pedigree), analyzed by RAPD and SSR markers according to the Vitis International Variety Catalogue (VIVC, 2011).

\begin{tabular}{|c|c|c|c|}
\hline Cultivar & Origin & Species & Pedigree \\
\hline Branca Salitre & Brazil & V. vinifera & \\
\hline Dattier de Beyrouth & Lebanon & V. vinifera & \\
\hline Beni Fuji & Japan & Hybrid & Golden Muscat x Kuroshio \\
\hline Beauty Seedless & USA & V. vinifera & Reine des Vignes x Black Kishmish \\
\hline Seyve Villard 20-365 & France & Hybrid & Panse de Provence x Seyve Villard 12375 \\
\hline Marroo Seedless & Australia & Hybrid & Carolina Blackrose x Ruby Seedless \\
\hline BRS Linda & Brazil & V. vinifera & CNPUV 154-90 x Saturn \\
\hline Red Globe & USA & V. vinifera & (Hunisa $\mathrm{x}$ Emperor) $\mathrm{x}$ (Hunisa $\mathrm{x}$ Emperor $\mathrm{x}$ Nocera) \\
\hline Muscat of Alexandria & Egypt & V. vinifera & \\
\hline Cardinal & USA & V. vinifera & Flame Tokay x Ribier \\
\hline Feal & Portugal & V. vinifera & \\
\hline A 1581 & USA & Hybrid & \\
\hline Centennial Seedless & USA & V. vinifera & Gold X Q25-6 (F2 de Emperor x Italia) \\
\hline Perlette & USA & V. vinifera & Regina del Vigneti x Sultanina \\
\hline Canner & USA & V. vinifera & Hunisa x Sultanina \\
\hline Ruby Seedless & USA & V. vinifera & Emperor x Sultana Moscata \\
\hline Flame Seedless & USA & V. vinifera & (Cardinal x Thompson) $\mathrm{x}$ (Red Malaga x Tefafini Ahmer) $\mathrm{x}$ (Muscat of Alexandria $\mathrm{x}$ Thompson) \\
\hline Venus & USA & Hybrid & Alden x New York 46000 \\
\hline Fiesta & USA & V. vinifera & \\
\hline July Muscat & USA & V. vinifera & $\begin{array}{l}\text { California 126-11 (Muscat of Alexandria x Flame Tokay) x California K4-41 (Muscat Hamburg } \\
\text { x Koenigin Der Weingaerten) }\end{array}$ \\
\hline Kyoho & Japan & Hybrid & Centennial x Ishihara Wase \\
\hline A 1105 & USA & Hybrid & \\
\hline A 1118 & USA & Hybrid & \\
\hline Patrícia & Brazil & Hybrid & Soraya x IAC 544-14 \\
\hline Estevão Marinho & France & V. vinifera & \\
\hline Italia & Italy & V. vinifera & Bicane x Muscat Hamburg \\
\hline Blush Seedless & USA & V. vinifera & Emperor x [Koenigin Der Weingaerten x (Alphonse Lavallee x Sultana Moscata)] \\
\hline Piratininga & Brazil & V. vinifera & IAC $842-4$ clone \\
\hline Brasil & Brazil & V. vinifera & Italia clone \\
\hline Crimson Seedless & USA & V. vinifera & Emperor x C33-199 \\
\hline Dawn Seedless & USA & V. vinifera & Gold x Perlette \\
\hline Thompson Seedless & Turquey & V. vinifera & \\
\hline Princess & USA & Hybrid & Crimson Seedless x B40-208 \\
\hline Muscat Hamburg & Germany & V. vinifera & Schiava Grossa x Muscat of Alexandria \\
\hline Ferlongo & Portugal & V. vinifera & Ferral x Alphonse Lavallee \\
\hline Benitaka & Brazil & V. vinifera & Italia clone \\
\hline Christmas Rose & USA & V. vinifera & (Hunisa $\mathrm{x}$ Emperor $\mathrm{x}$ Nocera) $\mathrm{x}$ (Hunisa $\mathrm{x}$ Emperor $\mathrm{x}$ Italia) \\
\hline A Dona & Brazil & Hybrid & Soraya x IAC 544-14 \\
\hline Moscatel Nazareno & Egypt & V. vinifera & Muscat Hamburg x Joao Santarem \\
\hline BRS Morena & Brazil & V. vinifera & Marroo Seedless x Centennial Seedless \\
\hline BRS Clara & Brazil & V. vinifera & CNPUV 154-147 x Centennial Seedless \\
\hline Juliana & Brazil & Hybrid & Italia x Madalena (IAC 21-14) \\
\hline Seyve Villard 12375 & France & Hybrid & Seibel 6468 x Seibel 6905 \\
\hline Lakemont Seedless & USA & Hybrid & Ontario x Thompson Seedless \\
\hline Dona Maria & Portugal & Hybrid & Moscatel of Setubal x Rosaki \\
\hline Niagara Rosada & Brazil & V. labrusca & Niagara clone \\
\hline Isabella Precoce ${ }^{(1)}$ & USA & V. labrusca & Isabella clone \\
\hline
\end{tabular}

\footnotetext{
${ }^{(1)}$ The cultivar Isabella Precoce is named Isabel Precoce in Brazil.
} 


\section{Results and Discussion}

Out of the 140 RAPD primers tested, only 20 produced reproducible and polymorphic bands. One hundred and eleven loci were identified, which represented $81.6 \%$ of total amplified bands. The number of recordable loci for each primer ranged from 1 to 10 with an average of 5.5. The size of amplification products ranged from 380 to $3,000 \mathrm{pb}$.

The polymorphism level found in the present work was higher than in previous studies on grapevine (Luo \& He, 2001; Narvaéz et al., 2001; Borrego et al., 2002; Ulanovsky et al., 2002). According to Tamhankar et al. (2001), the polymorphism levels depend on the analyzed species; these authors obtained $94 \%$ of polymorphism for wild grapevine species and rootstocks, and more than $90 \%$ for Vitis vinifera genotypes; however, almost all bands were monomorphic among Vitis labrusca. The patterns obtained by RAPD analysis are primer and sample-dependent (Luo \& He, 2001). The number of RAPD bands scored is also important to obtain accurate estimates of genetic relationships. The clustering in the dendrogram is completely rearranged if the number of scored bands is 100150. The estimation of genetic distances improved with the progressive increase of the number of bands (Fanizza et al., 2000). The number of scored bands in the present study is in accordance with Narváez et al. (2001), Pinto-Carnide et al. (2003), and Kocsis et al. (2005).

The 47 table grape accessions produced 75 distinct allelic profiles, when analyzed at seven SSR loci. Total number of alleles per locus ranged from nine (VVMD5) to 13 (VVS2), producing an average of 10.7 alleles per locus, which is higher than the number reported in previous works (Sefc et al., 2000; Aradhya et al., 2003; Ibáñez et al., 2003; Martínez et al., 2006; Almadanim et al., 2007; Fernandéz-González et al., 2007). Heterozygosity values obtained with the set of 47 accessions were high, between $74.5 \%$ at locus VVMD31 and $84.7 \%$ at VrZAG79, which also had the highest value for polymorphic information content (PIC) (83.0\%) (Table 2). Estimated frequency of rare alleles (below 5\%) was $48.7 \%$. The most frequent alleles per locus were VVMD5-236(27.3\%), VVMD7-239 (29\%), VVMD27-194 (26.6\%), VVMD31-212 (42.3\%), VVS2-135 (22.6\%), VrZAG79-255 (24.4\%) and VrZAG62-189 (38.3\%).
The values of genetic distance based on the Jaccard's coefficient ranged from 0.25 , between the intravarietal 'Itália' clones 'Italia Muscat' and 'Brasil', which were the most closely related accessions, to 0.68 between 'Piratininga' and 'Niagara Rosada', the most distantly related accessions. The closest genetic relationships among 'Italia' clones ('Italia Muscat', 'Benitaka' and 'Brasil') had been expected and are in accordance with previous works in Brazil for the cultivar Italia and its red bud sports (Leão et al., 2009).

The genetic similarity coefficient, used for microsatellite data, was the arithmetic complement of the weighted index, with values of genetic distances ranging from 0 to 1 , in which 0 is the coincidence of all alleles and indicates that the pair of accessions corresponds to a same genotype, and 1 is the pair of accessions that shares no alleles and shows maximum genetic distance.

The 20 RAPD primers analyzed in the present study could distinguish all accessions. However, the results based on seven SSR loci showed coincidence of allelic profiles for three pairs of accessions - 'Thompson Seedless' and 'Canner', 'A1581' and 'A1105', and 'Centennial Seedless' and 'Dawn Seedless' -, suggesting a close genetic relationship between them. The number of primers sufficient for reliable varietal identification depends on the nature and discriminating power of each primer (Tessier et al., 1999). Normally, six primer pairs are sufficient for differentiating between genotypes (This et al., 2004), but closely related cultivars require a larger number of primers (Meredith et al., 1999). In the present study, the seven SSR loci recommended by the GEN-RE081 project were not sufficient for differentiating the 47 genotypes obtained.

The clusters and dendrograms, regardless of the multivariate analysis method, showed variations

Table 2. Number of alleles, allele size range, expected heterozygosity (He), polymorphic information content (PIC) and maximum frequency of allele of the seven loci used for SSR analysis of 47 table grape accessions.

\begin{tabular}{lccccc}
\hline Locus & $\begin{array}{c}\text { Number } \\
\text { of alleles }\end{array}$ & $\begin{array}{c}\text { Allele size } \\
(\mathrm{pb})\end{array}$ & $\begin{array}{c}\mathrm{He} \\
(\%)\end{array}$ & $\begin{array}{c}\text { PIC } \\
(\%)\end{array}$ & $\begin{array}{c}\mathrm{F}_{\text {maximum }} \\
(\%)\end{array}$ \\
\hline VVS2 & 13 & $123-157$ & 84.1 & 82.2 & 21.2 \\
VVMD5 & 9 & $226-264$ & 81.2 & 78.8 & 27.6 \\
VVMD7 & 11 & $231-253$ & 84.0 & 82.2 & 27.6 \\
VVMD27 & 11 & $177-199$ & 80.7 & 78.0 & 26.6 \\
VVMD31 & 10 & $196-224$ & 74.7 & 71.8 & 42.5 \\
VrZAG62 & 11 & $181-207$ & 78.1 & 75.9 & 39.3 \\
VrZAG79 & 11 & $237-265$ & 84.7 & 83.0 & 29.4 \\
\hline
\end{tabular}


depending on the molecular marker used, which is in agreement with Merdinoglu et al. (2000), who mention that, although RAPD, SSR and amplified fragment length polymorphism (AFLP) have been able to distinguish seven groups of grape cultivars, the topology of the dendrograms was specific for each marker, and that SSR better reflects the genetic relationships between groups and their geographical origin. According to Pinto-Carnide et al. (2003), both molecular markers were able to identify Portuguese grape varieties, but the advantage of microsatellites is that they allow for comparison between different laboratories.

Tocher's cluster analysis applied to RAPD data showed 15 groups (Table 1). The main group concentrated $54.2 \%$ of the accessions and was subdivided into 10 subgroups. RAPD was efficient to distinguish $V$. vinifera $\mathrm{L}$. and $V$. labrusca $\mathrm{L}$. species. 'Italia Muscat', 'Brasil' and 'Benitaka' are bud sport clones of 'Italia'; they were in the same cluster and also in the same subgroup, which confirmed the closest genetic distances obtained among them. Tamhankar et al. (2001) also observed the clustering of bud sport selections from 'Thompson Seedless' grown in India.

The Tocher's cluster analysis based on microsatellites resulted in six groups. There was a main group with $76.6 \%$ of the accessions (Table 3 ), which was divided into 11 subgroups.

A dendrogram was generated based on the UPGMA analysis using RAPD markers and could distinguish 11 groups when a relative genetic distance of $86.6 \%$ at the cut point was considered. The first main group was composed of 30 accessions (63.8\%). The second one included six accessions: 'Venus', 'Blush Seedless', 'A1105', 'A1118', 'Cardinal' and 'Beni Fuji', showing similarity to group 3 obtained by Tocher's method. 'Flame Seedless' and 'Juliana' were joined in the fourth group. V. labrusca cultivars, 'Isabella Precoce' and 'Niagara Rosada', similarly to which occurred using Tocher's cluster analysis, were together in another group, with 0.40 of genetic similarity. The 'BRS Clara', 'Beauty Seedless', 'BRS Morena', 'Christmas Rose', 'Maria' and 'Piratininga' accessions were each separated in a distinct group, because they were distantly related to the rest of the accessions (Figure 1).

The first major group was subdivided in 12 subgroups with a genetic distance of $73.6 \%$ at the cut point. The dendrogram was correlated with the genealogy of accessions. Subgroup 1 was composed by 'Italia' clones
- 'Italia Muscat', 'Brasil' and 'Benitaka' - and 'Moscatel Nazareno'. 'Moscatel Nazareno' and 'Italia' have 'Muscat Hamburg' as their common parents. Another subgroup

Table 3. Clustering according to Tocher's method, for 47 table grape accessions based on 111 RAPD and seven SSR loci.

\begin{tabular}{|c|c|c|c|}
\hline \multicolumn{2}{|r|}{ RAPD } & \multicolumn{2}{|r|}{ SSR } \\
\hline Group & Accession & Group & Accession \\
\hline \multirow[t]{6}{*}{$1-1$} & Italia & $1-1$ & A 1105 \\
\hline & Brasil & & A 1581 \\
\hline & Benitaka & & A 1118 \\
\hline & Muscat Hamburg & $1-2$ & Canner \\
\hline & Lakemont Seedless & & Thompson Seedless \\
\hline & Moscatel Nazareno & & Blush Seedless \\
\hline \multirow[t]{2}{*}{$1-2$} & A 1581 & & Flame Seedless \\
\hline & Seyve Villard 12375 & & Fiesta \\
\hline \multirow[t]{5}{*}{$1-3$} & Dattier de Beyrouth & & Lakemont Seedless \\
\hline & Kyoho & & Beauty Seedless \\
\hline & Branca Salitre & $1-3$ & Centennial Seedless \\
\hline & Marroo Seedless & & Dawn Seedless \\
\hline & Ruby Seedless & & BRS Clara \\
\hline \multirow[t]{4}{*}{$1-4$} & BRS Linda & & Branca Salitre \\
\hline & Dawn Seedless & $1-4$ & Ferlongo \\
\hline & Patrícia & & Moscatel Nazareno \\
\hline & Thompson Seedless & $1-5$ & Crimson Seedless \\
\hline \multirow[t]{2}{*}{$1-5$} & A 1105 & & BRS Linda \\
\hline & A 1118 & & Ruby Seedless \\
\hline \multirow[t]{2}{*}{$1-6$} & Crimson Seedless & & Marroo Seedless \\
\hline & Princess & & Christmas Rose \\
\hline \multirow[t]{2}{*}{$1-7$} & Red Globe & & Red Globe \\
\hline & Estevão Marinho & $1-6$ & Benitaka \\
\hline $1-8$ & Fiesta & & Italia \\
\hline $1-9$ & Canner & & A Dona \\
\hline $1-10$ & Seyve Villard 20365 & $1-7$ & July Muscat \\
\hline \multirow[t]{4}{*}{2} & Centennial Seedless & & Piratininga \\
\hline & Perlette & & Beni Fuji \\
\hline & Feal & & Perlette \\
\hline & Piratininga & & Muscat Hamburg \\
\hline \multirow[t]{3}{*}{3} & Venus & $1-8$ & Dona Maria \\
\hline & Blush Seedless & & Estevão Marinho \\
\hline & Cardinal & & Muscat of Alexandria \\
\hline \multirow[t]{2}{*}{4} & Niagara Rosada & $1-9$ & Juliana \\
\hline & Isabella Precoce & $1-10$ & Cardinal \\
\hline \multirow[t]{2}{*}{5} & Beauty Seedless & $1-11$ & BRS Morena \\
\hline & July Muscat & 2 & Seyve Villard 12375 \\
\hline 6 & BRS Morena & & Seyve Villard 20365 \\
\hline 7 & Beni Fuji & 3 & Brasil 24 \\
\hline 8 & A Dona & & Patrícia \\
\hline 9 & Muscat of Alexandria & & Isabella Precoce \\
\hline 10 & Dona Maria & 4 & Dattier de Beyrouth \\
\hline 11 & BRS Clara & & Feal \\
\hline 12 & Christmas Rose & & Princess \\
\hline 13 & Juliana & 5 & Niagara Rosada \\
\hline 14 & Ferlongo & & Venus \\
\hline 15 & Flame Seedless & 6 & Kyoho \\
\hline
\end{tabular}


was formed by 'Crimson Seedless' and 'Princess', the first being a parent of the second. 'Red Globe' and 'Ruby Seedless' formed a third subgroup; both are descendants of the cultivar Emperor. However, the descendants of 'Thompson seedless' - 'Canner', 'Fiesta', 'Lakemont Seedless' and 'Perlette' - were separated into distinct subgroups.

In the dendrogram generated from the matrix of pairwise distances, based on microsatellite data, five main groups were distinguished with a genetic distance of $84 \%$ at the cut point (Figure 2). The first group was the largest, containing 38 accessions or $80.8 \%$ of all the analyzed accessions. The second group was similar to group 4 obtained by Tocher's method, and was composed of 'Dattier Beyrouth', 'Princess' and 'Feal'. The French hybrids 'Seyve Villard 12375' and 'Seyve Villard 20365' formed a third group, coinciding with the Tocher group 2. 'Niagara Rosada', 'Isabella Precoce' and 'Venus' were included in the fourth group. The largest genetic distance was obtained for the cultivar Kyoho $(d=0.897)$, isolated in group 5. The UPGMA method allowed for clustering of the 'Niagara Rosada' and 'Isabella Precoce' (both from $V$. labrusca) in the same group. This was not observed when the data were analyzed by Tocher's method. 'Venus' is in the same group; it is an interspecific hybrid from the University of Arkansas and has also V. labrusca in its genetic background.

The first group was subdivided in nine subgroups with a genetic distance of $66.76 \%$ at the cut point. Subgroup 1 in this dendrogram corresponded to Tocher subgroup 2. Interestingly, all accessions in this group

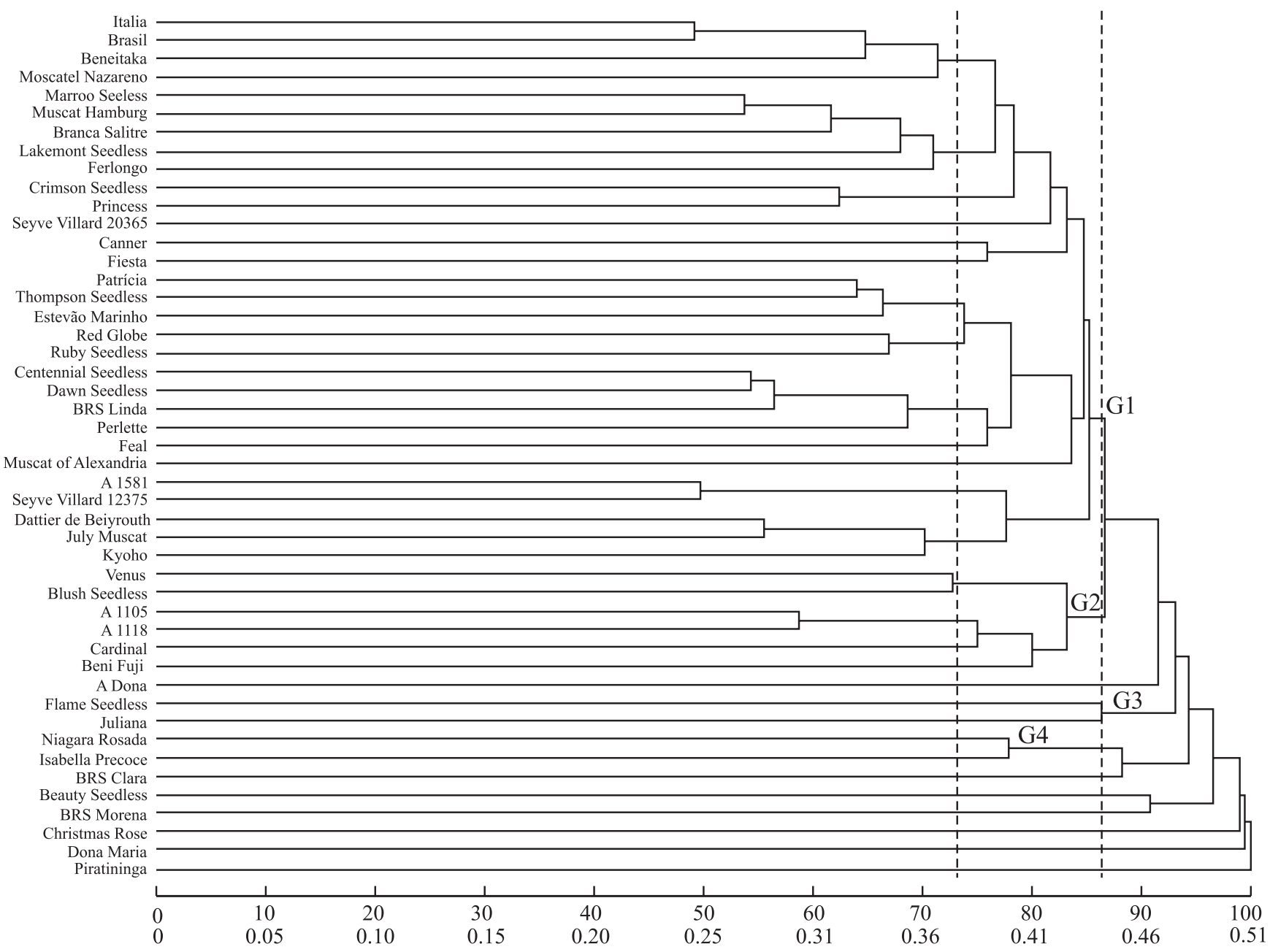

Figure 1. Cluster analysis of 47 table grape accessions by the UPGMA clustering using Jaccard's dissimilarity index, based on 111 RAPD molecular markers. The four main groups are identified as G1, G2, G3 and G4. 
(except for 'Blush Seedless') are descendants from 'Thompson Seedless'. 'Blush Seedless' showed no relationships with the other accessions, and, therefore, did not share alleles with them, which shows a possible misnaming or a genotyping error.

Subgroup 2 coincided with subgroup 1 by Tocher's method, including selections coming from the grape breeding program of the University of Arkansas ('A1105', 'A1581' and 'A1118'). Subgroup 3 was similar to subgroup 5, obtained by Tocher's method, and was composed of cultivars which have 'Emperor' as a common parent (except 'BRS Linda'). Subgroup 4, formed by cultivars Dona Maria, Muscat of Alexandria and Estevão Marinho, was the same as subgroup 8 by Tocher's method. 'Muscat of Alexandria' is a parent of the Portuguese 'Dona Maria'.

'Centennial Seedless', 'Dawn Seedless', 'BRS Clara', 'Branca Salitre' and 'BRS Morena' formed the fifth subgroup and differed from the subgroup 3 of Tocher's method due to the inclusion of'BRS Morena'. However,

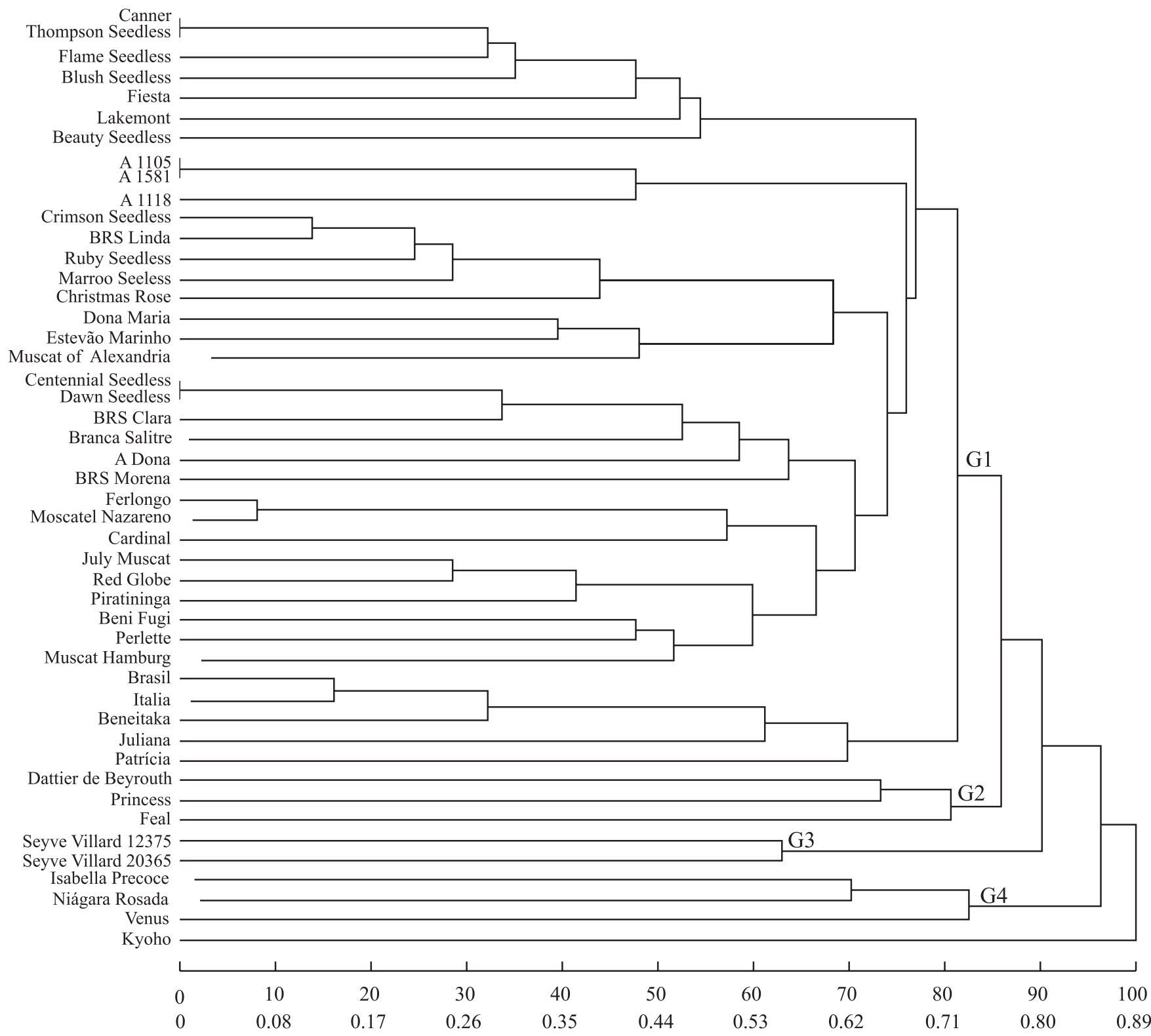

Figure 2. Cluster analysis of 47 table grape accessions by the UPGMA clustering, using the arithmetic complement of weighted index based on seven microsatellite markers. The four main groups are identified as G1, G2, G3 and G4. 
if the cut for genetic distance in the dendrogram was $56.15 \%$, the latter two cultivars were separated into distinct subgroups, leading to a complete coincidence between the subgroups obtained by both cluster analysis methods.

The genealogy of 'Ferlongo' and 'Cardinal' has 'Alphonse Lavalle' as a common parent. They were included in subgroup 6 with 'Moscatel Nazareno'.

Subgroup 7 was composed by six cultivars: 'July', 'Red Globe', 'Piratininga', 'Beni Fuji', 'Perlette' and 'Muscat Hamburg', and was similar to the subgroup of Tocher's analysis. In this subgroup, 'July Muscat', 'Piratininga' and 'Beni Fuji' share 'Muscat Hamburg' in their genetic background. 'Brasil', 'Italia Muscat' and 'Benitaka', bud sports of cultivar Italia, and the cultivar Juliana were included in subgroup 8. 'Juliana' shared $50 \%$ of alleles with 'Italia Muscat', since 'Italia' is one of its ancestors. The Brazilian accession 'Patricia', was separated into subgroup 9. In the present study, microsatellites could distinguish Brazilian intravarietal clones. According to Cretazzo et al. (2010), in a similar study in Spain, the most efficient technique to distinguish clones within autochthonous cultivars was M-AFLP.

Both cluster analysis methods showed a good agreement in the formation of groups; however, UPGMA resulted in a greater consistency between groups and cultivar genealogies. Microsatellites were more efficient than RAPD to study genetic relationships. Thus, the matrix of pairwise distances based on microsatellites was used to establish the five least related accessions (higher genetic distances) for ten seedless table grapes, which are important for their agronomic and commercial traits. Knowledge of the most divergent accessions is essential to guide the breeder in choosing the best combinations. However, other aspects should be considered to select parents for hybridization in addition to genetic divergence, such as the agronomic characteristics of cultivars, as well as breeding program goals.

In a table grape breeding program, whose main objective is the development of seedless grapes, the selection of parents should be based on the results shown in Table 4. For the development of new seedless grape cultivars, the strategy adopted by breeding programs worldwide has been the cross between two seedless grapes, followed by embryo rescue, which may increase the seedless trait frequency in the progenies
Table 4. Cultivars with the highest genetic distances from ten seedless table grape accessions, based on the arithmetic complement of the weighted index for SSR data.

\begin{tabular}{|c|c|}
\hline Cultivar & Genetic distance \\
\hline & A Dona \\
\hline Kyoho & 1.00 \\
\hline Flame Seedless & 0.93 \\
\hline Muscat of Alexandria & 0.91 \\
\hline A1105 & 0.87 \\
\hline \multirow[t]{2}{*}{ Muscat Hamburg } & 0.87 \\
\hline & BRS Clara \\
\hline Isabella Precoce & 1.00 \\
\hline Christmas Rose & 0.94 \\
\hline Marroo Seedless & 0.93 \\
\hline Moscatel Nazareno & 0.93 \\
\hline \multirow{2}{*}{ BRS Morena } & 0.93 \\
\hline & BRS Linda \\
\hline Isabella Precoce & 0.94 \\
\hline Brasil & 0.93 \\
\hline Crimson Seedless & 0.87 \\
\hline Juliana & 0.87 \\
\hline \multirow[t]{2}{*}{ Red Globe } & 0.86 \\
\hline & BRS Morena \\
\hline Brasil & 1.00 \\
\hline Estevão Marinho & 0.93 \\
\hline Christmas Rose & 0.93 \\
\hline BRS Clara & 0.93 \\
\hline \multirow[t]{2}{*}{ Flame Seedless } & 0.85 \\
\hline & Centennial Seedless \\
\hline Brasil & 0.94 \\
\hline Christmas Rose & 0.94 \\
\hline A Dona & 0.87 \\
\hline Lakemont Seedless & 0.87 \\
\hline \multirow[t]{2}{*}{ Estevão Marinho } & 0.86 \\
\hline & Crimson Seedless \\
\hline Ferlongo & 0.93 \\
\hline Lakemont Seedless & 0.93 \\
\hline BRS Linda & 0.87 \\
\hline Cardinal & 0.87 \\
\hline \multirow[t]{2}{*}{ Italia } & 0.87 \\
\hline & Marroo Seedless \\
\hline Brasil & 1.00 \\
\hline BRS Clara & 0.93 \\
\hline Red Globe & 0.86 \\
\hline July Muscat & 0.85 \\
\hline \multirow[t]{2}{*}{ Lakemont Seedless } & 0.84 \\
\hline & Perlette \\
\hline Kyoho & 0.93 \\
\hline Blush Seedless & 0.93 \\
\hline Dattier de Beyrouth & 0.91 \\
\hline Isabella Precoce & 0.91 \\
\hline \multirow[t]{2}{*}{$\underline{\text { Branca Salitre }}$} & 0.87 \\
\hline & Princess \\
\hline Brasil & 0.94 \\
\hline Christmas Rose & 0.94 \\
\hline A Dona & 0.87 \\
\hline Lakemont Seedless & 0.87 \\
\hline \multirow[t]{2}{*}{ Feal } & 0.86 \\
\hline & Thompson Seedless \\
\hline Lakemont Seedless & 0.94 \\
\hline Estevão Marinho & 0.93 \\
\hline Isabella Precoce & 0.91 \\
\hline Christmas Rose & 0.88 \\
\hline A 1105 & 0.87 \\
\hline
\end{tabular}


by 50 to $80 \%$ (Lahogue et al., 1998). Therefore, crossings could be recommended between 'A Dona' and 'Centennial Seedless' and 'Princess', using the embryo rescue technique. Still, aiming to incorporate resistance to fungal diseases, 'Isabella Precoce' should be used for its moderate resistance to bacterial canker and may also be used to obtain interspecific hybrids in crosses with 'BRS Clara', 'BRS Linda', 'Thompson Seedless' and 'Perlette'. The cross 'Thompson Seedless' x 'Isabella Precoce' can still be a good option to obtain mapping populations, in the search for genes linked to seedless characteristic and to resistance to bacterial canker trait.

\section{Conclusions}

1. RAPD markers are sufficient to distinguish all table grape accessions analyzed; however, microsatellites are only able to distinguish cultivars.

2. The cluster analyses using Tocher and UPGMA methods have a good agreement in group formation, and UPGMA provides a better consistency between groups and genealogy.

3. There was no relation between the dissimilarity matrix, formation of groups and topology of dendrograms, when RAPD and microsatellite data were used.

4. Assessment of genetic diversity of a subset of table grape cultivars, in addition to the knowledge of their agronomic characteristics, allow for the recommendation of crosses between seedless grapes, which can contribute to the table grape breeding program in Northeastern Brazil.

\section{References}

ALMADANIM, M.C.; BALEIRAS-COUTO, M.M.; PEREIRA, H.S.; CARNEIRO, L.C.; FEVEREIRO, P.; EIRA-DIAS, J.E.; MORAIS-CECILIO, L.; VIEGAS, W.; VELOSO, M.M. Genetic diversity of the grapevine (Vitis vinifera L.) cultivars most utilized for wine production in Portugal. Vitis, v.46, p.116-119, 2007.

ARADHYA, M.K.; DANGL, G.S.; PRINS, B.H.; BOURSIQUOT, J.-M.; WALKER, M.A.; MEREDITH, C.P.; SIMON, C.J. Genetic structure and differentiation in cultivated grape, Vitis vinifera L. Genetical Research, v.81, p.179-192, 2003.

BORREGO, J.; DE ANDRÉS, M.T.; GÓMEZ, J.L.; IBÁNEZ, J. Genetic study of Malvasia and Torrontes groups through molecular markers. American Journal of Enology and Viticulture, v.53, p.125-130, 2002.

BOWERS, J.E.; DANGL, G.S.; MEREDITH, C.P. Development and characterization of additional microsatellite DNA markers for grape. American Journal of Enology and Viticulture, v.50, p.243-246, 1999.

BOWERS, J.E.; DANGL, G.S.; VIGNANI, R.; MEREDITH, C.P. Isolation and characterization of new polymorphic simple sequence repeat loci in grape (Vitis vinifera L.). Genome, v.39, p.628-633, 1996.

COSTANTINI, L.; MONACO, A.; VOUILLAMOZ, J.F.; FORLANI, M.; GRANDO, M.S. Genetic relationships among local Vitis vinifera cultivars from Campania (Italy). Vitis, v.44, p.25-34, 2005.

CRETAZZO, E.; MENEGHETTI, S.; DE ANDRÉS, M.T.; GAFORIO, L.; FRARE, E.; CIFRE, J. Clone differentiation and varietal identification by means of SSR, AFLP, SAMPL and M-AFLP in order to assess the clonal selection of grapevine: the case study of Manto Negro, Callet and Moll, autochthonous cultivars of Majorca. Annals of Applied Biology, v.157, p.213-227, 2010.

CRUZ, C.D. Programa Genes: diversidade genética. Viçosa: UFV, 2008. 307p.

CRUZ, C.D.; REGAZZI, A.J.; CARNEIRO, P.C. de S. Modelos biométricos aplicados ao melhoramento genético. 3.ed. Viçosa: UFV, 2004. 480p.

FANIZZA, G.; CORONA, M.G.; RESTA, P. Analysis of genetic relationships among Muscat grapevines in Apulia (South Italy) by RAPD markers. Vitis, v.39, p.159-161, 2000.

FATAHI, R.; EBADI, A.; BASSIL, N.; MEHLENBACHER, S.A.; ZAMANI, Z. Characterization of Iranian grapevine cultivars using microsatellite markers. Vitis, v.42, p.185-192, 2003.

FERNÁNDEZ-GONZÁLEZ, M.; MENA, A.; IZQUIERDO, P.; MARTÍNEZ, J. Genetic characterization of grapevine (Vitis vinifera L.) cultivars from Castilla la Mancha (Spain) using microsatellite markers. Vitis, v.46, p.126-130, 2007.

HERRERA, R.; CARES, V.; WILKINSON, M.J.; CALIGARI, P.D.S. Characterization of genetic variation between Vitis vinifera cultivars from central Chile using RAPD and Inter simple sequence repeat markers. Euphytica, v.124, p.139-145, 2002.

IBÁÑEZ, J.; DE ANDRÉS, M.T.; MOLINO, A.; BORREGO, J. Genetic study of key Spanish grapevine varieties using microsatellite analysis. American Journal of Enology and Viticulture, v.54, p.22-29, 2003.

KOCSIS, M.; JÁROMI, L.; PUTNOKY, P.; KOZMA, P.; BORHIDI, A. Genetic diversity among twelve grape cultivars indigenous to the Carpathian Basin revealed by RAPD markers. Vitis, v.44, p.87-91, 2005.

LAHOGUE, F.; THIS, P.; BOUQUET, A. Identification of a codominant scar marker linked to the seedless character in grapevine. Theoretical Applied Genetics, v.97, p.950-959, 1998.

LEÃO, P.C.S.; RIAZ, S.; GRAZIANI, R.; DANGL, G.S.; MOTOIKE, S.Y.; WALKER, M.A. Characterization of a Brazilian grape germplasm collection using microsatellite markers. American Journal of Enology and Viticulture, v.60, p.517-524, 2009.

LODHI, M.A.; YE, G.-N.; WEEDEN, N.F.; REISCH, B.I. A simple and efficient method for DNA extraction from grapevine cultivars and Vitis species Ampelopsis. Plant Molecular Biology Reporter, v.12, p.6-13, 1994. 
LUO, S.; HE, P. Discrimination of wild grapes native to China by RAPD markers. Vitis, v.40, p.163-168, 2001.

MARTÍNEZ, L.E.; CAVAGNARO, P.F.; MASUELLI, R.W.; ZÚÑIGA, M. SSR-based assessment of genetic diversity in South American Vitis vinifera varieties. Plant Science, v.170, p.1036-1044, 2006.

MERDINOGLU, D.; BUTTERLIN, G.; BAUR, C.; BALTHAZARD, J. Comparison of RAPD, AFLP and SSR (microsatellite) markers for genetic diversity analysis in Vitis vinifera L. Acta Horticulturae, v.528, p.193-195, 2000.

MEREDITH, C.P.; BOWERS, J.E.; RIAZ, S.; HANDLEY, V.; BANDMAN, E.B.; DANGL, G.S. The identity and parentage of the variety known in California as Petite Sirah. American Journal of Enology and Viticulture, v.50, p.236-242, 1999.

NARVÁEZ H., C.; CASTRO P., M.H.; VALENZUELA B., J.; HINRICHSEN R., P. Patrones genéticos de los cultivares de vides de vinificación más comúnmente usados en Chile basados en marcadores de microsatélites. Agricultura Técnica, v.61, p.249-261, 2001.

OLIVEIRA, P.R.D. de; SCOTTON, D.C.; NISHIMURA, D.S.; FIGUEIRA, A. Análise da diversidade genética por AFLP e identificação de marcadores associados à resistência a doenças em videira. Revista Brasileira de Fruticultura, v.27, p.454-457, 2005.

PINTO-CARNIDE, O.; MARTIN, J.P.; LEAL, F.; CASTRO, I.; GUEDES-PINTO, H.; ORTIZ, J.M. Characterization of grapevine (Vitis vinifera L.) cultivars from Northern Portugal using RAPD and microsatellite markers. Vitis, v.42, p.23-25, 2003.

RITSCHEL, P.S.; CAMARGO, U.A.; MAIA, J.D.G.; REVERS, L.F. Towards the developing of well adapted grapes for tropical regions. Acta Horticulturae, v.872, p.421-425, 2010.

SEFC, K.M.; LOPES, M.S.; LEFORT, F.; BOTTA, R.; ROUBELAKIS-ANGELAKIS, K.A.; IBÁÑEZ, J.; PEJIĆ, I.; WAGNER, H.W.; GLÖSSL, J.; STEINKELLNER, H. Microsatellite variability in grapevine cultivars from different European regions and evaluation of assignment testing to assess the geographic origin of cultivars. Theoretical and Applied Genetics, v.100, p.498-505, 2000 .

SEFC, K.M.; REGNER, F.; TURETSCHEK, E.; GLÖSSL, J.; STEINKELLNER, H. Identification of microsatellite sequences in Vitis riparia and their applicability for genotyping of different Vitis species. Genome, v. 42, p.367-373, 1999.

TAMHANKAR, S.A.; PATIL, S.G.; RAO, V.S. Assessment of the genetic diversity of some important grape genotypes in India using RAPD markers. Vitis, v.40, p.157- 161, 2001.

TESSIER, C.; DAVID, J.; THIS, P.; BOURSIQUOT, J.M.; CHARRIER, A. Optimization of the choice of molecular markers for varietal identification in Vitis vinifera L. Theoretical and Applied Genetics, v.98, p.171-177, 1999.

THIS, P.; JUNG, A.; BOCCACCI, P.; BORREGO, P.; BOTTA, R.; COSTANTINI, L.; CRESPAN, M.; DANGL, G.S.; EISENHELD, C.; FERREIRA-MONTEIRO, F.; GRANDO, S.; IBÁÑEZ, J.; LACOMBE, T.; LAUCOU, V.; MAGALHÃES, R.; MEREDITH, C.P.; MILANI, N.; PETERLUNGER, E.; REGNER, F.; ZULINI, L.; MAUL, E. Development of a standard set of microsatellite reference alleles for identification of grape cultivars. Theoretical and Applied Genetics, v.109, p.1448-1458, 2004.

THOMAS, M.R.; SCOTT, N.S. Microsatellite repeats in grapevine reveal DNA polymorphisms when analysed as sequence-tagged sites (STSs). Theoretical and Applied Genetics, v.86, p.985-990, 1993.

ULANOVSKY, S.; GOGORCENA, Y.; MARTÍNEZ DE TODA, F.; ORTIZ, J.M. Use of molecular markers in detection of synonymies and homonymies in grapevines (Vitis vinifera L.). Scientia Horticulturae, v.92, p.241-254, 2002.

VIVC. Vitis International Variety Catalogue [home page]. Available at: <http://www.vivc.de/index.php>. Accessed on: 29 Aug. 2011.

Received on May 5, 2011 and accepted on August 5, 2011 